FILOZOFIA

Roč. 75,2020 , с̌. 9

DOI: https://doi.org/10.31577/filozofia.2020.75.9.3

\title{
NATURALIZMUS A SKEPTICIZMUS
}

MARIANA SZAPUOVÁ, Filozofická fakulta Univerzity Komenského v Bratislave, Katedra filozofie a dejín filozofie, Bratislava, SR

MARTIN NUHLÍČEK, Filozofická fakulta Univerzity Komenského v Bratislave, Katedra filozofie a dejín filozofie, Bratislava, SR

SZAPUOVÁ, M., NUHLÍČEK, M.: Naturalism and Skepticism

FILOZOFIA, 75, 2020, No 9, pp. $760-775$

The problem of skepticism is one of the central problems in traditional epistemology which has its place also in contemporary analytically oriented epistemology. However, from the point of view of naturalized epistemology, skepticism is shifting to the periphery of interest. The subject of the paper is the relationship between skepticism and naturalism, which in contemporary epistemology are understood as opposing positions. Attention is focused on the critique of philosophical skepticism from the naturalistic perspective, as well as on the critique of the naturalistic reaction to skepticism from antinaturalist positions. The aim of the study is to clarify the main points of the dispute between the traditional approach and the naturalistic approach to knowledge inspired by Quine, with special regard to the problem of skepticism. The intention is to demonstrate that the dispute between traditional and naturalistic epistemology is not primarily concerned with skepticism, but it is a metaepistemological dispute concerning the nature or the very possibility and legitimacy of epistemology as a philosophical study in which the issue of epistemic normativity plays a central role.

Keywords: Epistemic normativity - Metaepistemology - Naturalistic epistemology Philosophical skepticism - W. V. O. Quine

\section{Úvod}

Predmetom tejto štúdie je vzt’ah skepticizmu a naturalizmu v súčasnej epistemológii. Kým problém skepticizmu patrí $\mathrm{k}$ najstarším, ale i najprovokatívnejším epistemologickým problémom, naturalizmus, hoci tiež má svoju tradíciu, sa stal reflektovaným a rozvíjaným epistemologickým postojom až v druhej polovici dvadsiateho storočia. Ako je známe, skeptická epistemologická stratégia sa vo svojej modernej podobe prvýkrát objavuje u Descarta, ktorý si vytyčuje stratégiu preskúmat' všetky svoje presvedčenia, spochybnit' všetko, o čom sa dá pochybovat', za účelom nájdenia neotrasitel'ných, pevných základov l'udského poznania a nespochybnitel'nej istoty. Takto zist'uje, že spochybnitel'né sú mnohé oblasti našich presvedčení vrátane takých, o ktorých by nás azda nikdy 
nenapadlo pochybovat'. Rozrôznenost' podôb či foriem platí aj pre naturalizmus. Ako neskôr ukážeme, výraz naturalizmus neoznačuje jeden unifikovaný prístup, ale celý zväzok rozličných, hoci príbuzných prístupov. To, čo robí vzt’ah medzi skepticizmom a naturalizmom zaujímavým, je skutočnost', že sú vnímané ako protichodné pozície, respektíve že naturalizmus sa často chápe ako „terapia“ na ,chorobu“ zvanú skepticizmus. Takéto chápanie sa viaže na ponímanie skepticizmu ako negatívneho epistemologického záveru (skeptického argumentu) popierajúceho možnost' poznania vonkajšieho sveta. Predbežne a zjednodušene povedané: $Z$ pohl'adu naturalistov sa problém skepticizmu nejaví ako skutočný problém hodný pozornosti, ale ako pseudoproblém, ktorý je dôsledkom tradičnej špekulatívnej epistemológie, ktorú chcú prekonat'. Ich reakcie na skepticizmus sú preto odmietavé, poukazujúce na nezmyselnost' či jalovost' skepticizmu, ako aj úsilia o jeho vyriešenie. No na druhej strane ani naturalistická pozícia nie je prijímaná ako bezproblémová a je vystavená rôznym druhom kritiky. Jeden druh takej kritiky poukazuje na to, že ak prijmeme naturalistické východiská, tak naše skúmanie poznania - paradoxne - skončí v skepticizme.

V tejto stati sa budeme venovat' vzt'ahu medzi skepticizmom a naturalizmom v epistemológii: bude nás zaujímat' kritika filozofického skepticizmu z naturalistickej perspektívy, ako aj kritika naturalistickej reakcie na skepticizmus z antinaturalistických pozícií. V prvej časti štúdie podáme stručnú charakteristiku naturalizmu a skepticizmu s ciel'om ozrejmit' naše chápanie týchto filozofických pozícií. Následne sa budeme venovat' Quinovmu projektu naturalizovanej epistemológie (d’alej NE) a osvetlíme kontrast medzi naturalizovanou a tradičnou epistemológiou (d'alej TE), do ktorej radíme aj súčasné nenaturalisticky orientované prístupy, vzhl'adom na problém skepticizmu. V d’alších častiach priblížime naturalistický pohl'ad na skepticizmus, ako aj niektoré body kritiky naturalistického prístupu k problému skepticizmu. Naším ciel’om je preukázat', že v spore medzi TE a NE nejde primárne o skepticizmus, ale je to spor metaepistemologický, $\mathrm{v}$ ktorom centrálnu úlohu zohráva otázka normativity.

\section{O skepticizme a naturalizme}

Filozofický skepticizmus je podl'a mnohých jeden z najzaujímavejších epistemologických problémov. Netvorí jednoliatu filozofickú doktrínu, ale skôr taký typ filozofického uvažovania o poznaní, ktorý obsahuje špecifické skeptické argumenty. Pod termínom skepticizmus možno chápat' jednoducho záver skeptického argumentu (Greif 2015, 532), pričom skeptické argumenty sú také argumenty, podla ktorých nič (alebo takmer nič) nevieme. To je v príkrom rozpore s tým, čo si bežne myslíme. Hoci pochybovanie je bežnou súčast'ou vedeckého diskurzu i každodenného života, filozofická skeptická pochybnost' ju presahuje svojou šírkou - v tom zmysle, že skeptikova pochybnost' sa netýka jednotlivých konkrétnych presvedčení, ale zasahuje naraz celé triedy 
presvedčení -, ako aj hĺbkou, ked’že artikuluje principiálne pochybnosti založené na silných argumentoch, ktoré nie je l'ahké, ba dokonca ani možné vyvrátit'. Hoci terčom skeptických pochybností môžu byt' rôzne oblasti, v súčasných diskusiách prevláda skepticizmus vo vzt'ahu $\mathrm{k}$ vonkajšiemu svetu ${ }^{1}$ a o tento druh skepticizmu nám pôjde aj $\mathrm{v}$ tejto stati. Oproti bežnému pochybovaniu tak skeptická pochybnost' nie je jednoznačným spôsobom rozhodnutel'ná - odvolat' sa pri pochybovaní o niečom, čo napríklad vnímame zrakom, na iné zmyslové presvedčenia, tak ako to robíme v bežnom živote, skepticizmus jednoducho neumožňuje. Pochybnost' ostáva neprekonatel’ná.

Tradičný karteziánsky skepticizmus je postavený na takom type skeptických argumentov, aké predstavil R. Descartes vo svojich Meditáciách o prvej filozofii. Ide o argumenty, ktoré pracujú so skeptickými hypotézami, respektíve scenármi, v ktorých nastáva rozsiahly omyl v našich presvedčeniach. Medzi najznámejšie skeptické scenáre patria hypotéza sna a hypotéza všemocného zlého ducha od R. Descarta či hypotéza mozgov v kadi od H. Putnama² (Descartes 1997, Putnam 1981). Spoločné majú to, že subjekt sa v nich ocitá $\mathrm{v}$ situácii rozsiahleho zavádzania spôsobeného vyspelou technológiou, nadprirodzenou silou a podobne, dôsledkom čoho určitá trieda jeho presvedčení nezodpovedá skutočnosti. Podstatné je, že v rámci skeptického scenára si subjekt takéhoto zavádzania nie je vedomý, a zo svojej perspektívy ani nemá prostriedky, aby rozlíšil, či je takouto obet’ou zavádzania alebo nie. Pointa skeptickej argumentácie však netkvie v tvrdení, že skeptické scenáre by mali byt' aktuálne pravdivé. Naopak, je postavená na „negatívnom“ princípe: kým nedokážeme vylúčit možnost', že sme obetou skeptického scenára, tak naše presvedčenia nie sú isté. A ked’že nevieme dokázat', že nenastali skeptické scenáre, tak takú istotu nemôžeme dosiahnut'. Dané scenáre sú totiž skonštruované práve tak, že ich neprítomnost' sa dokázat' nedá. Poznanie si však vyžaduje istotu, že sa nemýlime, a preto poznanie nemáme, uzatvára skeptik.

V reakciách na filozofický skepticizmus najčastejšie rezonujú snahy o nájdenie účinnej odpovede naň, prípadne o „diagnostikovanie“ chyby v skeptickom uvažovaní. Toto úsilie vyviera z implicitného chápania skepticizmu ako hrozby pre naše poznanie: kým neodstránime alebo nediskvalifikujeme skepticizmus, tak nemôžeme legitímne tvrdit', že máme poznanie. Jedna z aktuálne uplatňovaných stratégií, ako čelit' problému skepticizmu, vychádza z čoraz rozšírenejšieho naturalistického smeru v epistemológii.

Slovo naturalizmus, respektíve adjektívum naturalistický patrí v súčasnom filozofickom diskurze $\mathrm{k}$ frekventovaným termínom, pričom tieto termíny sa $\mathrm{v}$ súčasných

\footnotetext{
${ }^{1}$ Pozri bližšie (Nuhlíček, Szapuová 2012)

${ }^{2}$ Putnam však túto hypotézu nakoniec použiva na demonštráciu antiskeptického postoja na základe sémantických úvah.
} 
diskusiách použivajú v rôznych významoch a vystupujú v rozličných kontextoch. ${ }^{3}$ Súvisí to zrejme s tým, že naturalizmus je v súčasnosti široko rozšírený a možno ho pokladat' za všeobecnú filozofickú stratégiu, ktorá má svoje miesto v rozličných oblastiach filozofického skúmania; niektorí autori hovoria dokonca o naturalistickom obrate (pozri Stroud 1996). V literatúre venovanej filozofickému naturalizmu ${ }^{4}$ možno nájst' jeho rozličné vymedzenia a typológie. Niektorí autori rozlišujú formy naturalizmu podl’a ich viazanosti na jednotlivé filozofické disciplíny a v takomto zmysle hovoria o metafyzickom, etickom či epistemologickom naturalizme, prípadne o naturalizme vo filozofii vedy a vo filozofii mysle (pozri Haack 2010), iní pokladajú za základ rozlíšenie medzi naturalizmom v teoretickej a praktickej filozofii (Keil 2017, 26). P. F. Strawson člení naturalistické pozície podla ich sily, ked' rozlišuje medzi prísnym, reduktívnym a inkluzívnym, liberálnym naturalizmom (Strawson 1985, 1). Vzhl'adom na široké pole významov, $\mathrm{v}$ akých sa výraz naturalizmus $\mathrm{v}$ súčasných filozofických diskusiách vyskytuje, by bolo riskantné usilovat' sa o jeho presnú a dostatočne širokú definíciu. Na tomto mieste sa preto uspokojíme s upozornením, že slovo naturalizmus referuje skôr na prírodnú vedu ako na prírodu a na presvedčenie o epistemickej primárnosti, prípadne aj výlučnosti prírodnej vedy ako zdroja poznania sveta (Keil 2010, 263; Ryder 2002, 125).

Téza o epistemickej primárnosti vedy sa premieta aj do metafilozofickej roviny, do doktríny, podl'a ktorej sa filozofické problémy nemajú riešit' apriórne. Naturalizmus ako metafilozofická stratégia je zameraný na približovanie filozofie k (prírodným) vedám, prípadne nahradenie filozofie vedou, na popieranie priority filozofie voči vedám a najmä na zdôraznenie myšlienky, podl'a ktorej sa filozofické problémy v princípe dajú riešit' metódami empirických vied (De Caro, Macarthur 2004, 6). Vo všeobecnosti teda naturalistické pozície vo filozofii možno vnímat' ako rozvinutie základnej myšlienky, akcentujúcej rolu prírodovedy pri určovaní toho, čo jestvuje (metafyzický či ontologický naturalizmus) a pri zist’ovaní toho, ako sa veci majú (metodologický či epistemologický naturalizmus). ${ }^{5}$ Osobitne jasne je táto myšlienka prítomná v téze W. Sellarsa, ktorá ako istá alúzia na Protagorovu vetu homo mensura hovorí, že pri popise a vysvetlovaní sveta je veda mierou všetkých vecí (Sellars 1963, 173). ${ }^{6}$ Mimoriadne vplyvným

\footnotetext{
${ }^{3}$ Je príznačné, že O. Flanagan začína svoj výklad naturalizmu vymenovaním pätnástich rôznych významov, v akých sa termín naturalizmus vo filozofickej spisbe používa (Flanagan 2008, 430 - 431).

${ }^{4}$ Treba upozornit', že tu nejde o -izmus v zmysle nejakej presne ohraničenej a dobre vymedzenej doktríny, ale medzi naturalizmami ide skôr o wittgensteinovské rodinné príbuznosti, o viac či menej vol'né spojenia medzi filozofickými a metafilozofickými pozíciami či prístupmi, ktoré sa týkajú vedy, človeka či morálnych hodnôt.

${ }^{5}$ Intenzívne a široko diferencované diskusie sa vedú aj o naturalizme v etike a metaetike, ktoré si však nevšímame, ked’že priamo nesúvisia s témou tohto článku.

${ }^{6}$ Takýto vedecký či metodologický naturalizmus, blízky scientizmu, Keil výstižne pomenúva ako naturalizmus typu scientia mensura, ktorý je prítomný v uvažovaní mnohých vplyvných filozofov dvadsiateho storočia (Keil 2017, 27).
} 
proponentom takéhoto metodologického naturalizmu bol popri Sellarsovi bezpochyby

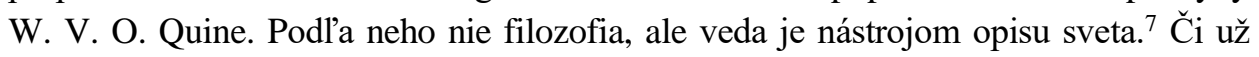
uvažujeme o vede a poznaní, o mysli alebo význame, musíme si uvedomit', že tieto „veci“ sú súčast’ou toho istého sveta, na ktorý sa vzt'ahujú, a preto majú byt' tiež skúmané empiricky, tak ako ostatné fenomény prírodného sveta (Quine 1969, 26).

V rámci tejto state pod naturalizmom budeme chápat' metodologický a epistemologický naturalizmus vo vyššie naznačenom zmysle. Je to naturalizmus metodologický, pretože sa týka spôsobu skúmania, a zároveň je to naturalizmus epistemologický, pretože sa týka poznania ako predmetu skúmania. Hlavné kontúry takéhoto naturalizmu načrtol W. V. O. Quine vo svojej programovej stati Naturalizácia epistemológie z roku 1969 (Quine 2006a). Od vydania tohto článku sa Quinov projekt rozvinul na širokú filozofickú a metafilozofickú stratégiu, ktorá má v súčasnosti nespočetných prívržencov i pokračovatel'ov. V oblasti epistemológie a filozofie vedy v programe naturalizácie pokračujú prístupy, ktoré volajú po empirickom výskume poznávacích procesov a procesov tvorby vedeckého poznania a zdôrazňujú význam sociológie vedy pre riešenie otázok tradične považovaných za oblast' apriórneho filozofického záujmu. H. Kornblith, pri ktorého názoroch sa ešte pristavíme, napríklad navrhuje pozorne si všímat' sociológiu poznania a tvrdí, že výskum sociálnych faktorov v procesoch poznávania je podstatnou súčast'ou naturalistického prístupu k epistemológii (pozri Kornblith 1994a). Výskumy v oblasti sociológie vedy pokladá za súčast' naturalizovaného prístupu aj B. Stroud (Stroud 1996, 47). Relevantnost' empirických výskumov pre filozofickú reflexiu vedy zdôrazňujú aj niektoré feministické epsitemologičky (pozri Longino 1990, Nelson 1990). Do prúdu naturalizácie možno napokon zaradit' aj novšie prístupy, rozvíjané v rámci takzvanej experimentálnej filozofie, ktoré navrhujú skúmat' epistemologické témy, napríklad problém objektivity vedy, prostredníctvom empirických a experimentálnych metód (pozri napr. Paitlová, Jedlička 2020).

\section{Quine o naturalizme a skepticizme}

Quinov programový článok Naturalizácia epistemológie (Epistemology Naturalized) z roku 1969 je bezpochyby nielen referenčným či východiskových bodom súčasných diskusií o NE, ale predstavuje aj prvotný zdroj naturalistických názorov na skepticizmus, a preto sa mu budeme venovat' prednostne. Quine v ňom do centra svojej pozornosti stavia problém poznania a vedy. ${ }^{8} \mathrm{Za}$ centrálnu považuje otázku, ako l’udia,

\footnotetext{
${ }^{7}$ Slovo veda Quine používa v širšom zmysle. Do pojmu vedy zahŕňa aj takzvané mäkké vedy od psychológie a ekonómie cez sociológiu až po históriu (Quine 2002, 78), ako aj takzvaný zdravý rozum.

${ }^{8}$ Treba podotknút', že naturalizmus je pre Quina nielen epistemologickou, ale ovel’a širšou platformou; je preňho všeobecnou filozofickou stratégiou (metafilozofickou a metodologickou). Niektorí
} 
obyvatelia fyzického sveta, tvoria svoje „teórie sveta“ a načrtáva svoj projekt naturalizovanej epistemológie. ${ }^{9}$ Problém poznania (či už bežného alebo vedeckého, medzi nimi Quine nevidí zásadný rozdiel) formuluje ako problém vzt’ahu medzi tým, čo nám o svete sprostredkujú naše zmysly a našou „teóriou sveta.“ Nadväzujúc na empiristickú tradíciu vychádza z presvedčenia, že poznanie o predmetoch vonkajšieho sveta nadobúdame výlučne prostredníctvom zmyslovej percepcie. Ide tu o problém, ktorý stojí v centre TE, o descartovské úsilie nájst' akési pevné základy a preukázat', ako sú naše presvedčenia o vonkajšom svete prepojené s týmito základmi či evidenciou. Ako je známe, Descartovo úsilie v Meditáciách neodvratne vedie $\mathrm{k}$ skeptickému záveru: Ak všetko naše poznanie pochádza zo zmyslov - pričom zmysly nás občas klamú, podobne ako naše sny -, tak neexistuje spôsob, ako preklenút' epistemickú priepast' medzi tým, ako sa nám vonkajší svet javí, a tým, aký v skutočnosti je. Inými slovami, ak prijmeme, že jediným základom (či dôvodom) všetkých presvedčení o svete je svedectvo našich zmyslov, a zároveň rozlišujeme medzi týmto svedectvom a tým, čo je pravdivé (alebo nepravdivé) o svete okolo nás, nemožno vylúčit' možnost', že svet sa diametrálne líši od toho, ako sa nám ukazuje v zmyslovej percepcii, a že naše presvedčenia sú mylné (pozri Stroud 1984, 208 - 209).

Quine sa ani nepokúša preukázat', že možnost' systematického a všeobecného omylu možno vylúčit', ba dokonca sa možno nazdávat', že prijíma skeptický záver, ku ktorému také úsilie vedie (Stroud 1981). Skeptickému záveru by sme sa mohli vyhnút' iba za predpokladu, že by sme disponovali nejakou nezávislou informáciou o tom, že zmysly sú spol'ahlivým nástrojom na poznanie toho, ako sa veci majú. Ak však prijmeme empiristickú pozíciu a zmysly budeme pokladat' za jediný zdroj poznania, l’ahko zistíme, že táto podmienka nikdy nemôže byt' splnená. Treba teda hl'adat' iný spôsob, ako zabezpečit' možnost' poznania vonkajšieho sveta. Pripomeňme, že skeptický záver je dôsledkom dôležitej dištinkcie medzi tým, čo je dané v zmyslovej skúsenosti, a tým, čo je o svete pravdivé, ako aj dôsledkom descartovského ponímania zmyslovej skúsenosti, ktorej obsahom sú mentálne stavy.

Quinov program naturalizácie epistemológie odmieta „karteziánsky sen o základoch vedeckej istoty, ktorá by bola pevnejšia než samotná vedecká metóda“ (Quine 1994, 27) a zaoberá sa otázkou, ktorá bola centrálna aj pre TE: otázkou vzt’ahu vedy $\mathrm{k}$ jej empirickým dátam, teda toho, ako na základe stimulácie našich zmyslov tvoríme našu teóriu sveta (tamže, 9). Tento problém Quine uchopuje ako problém vzt'ahu ,medzi vstupom a výstupom u l'udí mäsa a kostí“" (tamže, 27), kde vstup predstavuje

autori ho považujú za najvýraznejšieho predstavitel'a filozofického naturalizmu vôbec (Orenstein 2002, 173).

${ }^{9}$ Termín epistemológia Quine často používa v zmysle filozofie vedy, respektíve nerozlišuje medzi epistemológiou a filozofiou vedy. 
podráždenie zmyslových receptorov a výstup našu teóriu sveta. NE je v jeho ponímaní empirické štúdium toho, ako človek zo stimulácie zmyslových receptorov produkuje teóriu sveta. Študuje vzt'ah medzi ludskou bytost'ou a jeho prostredím a pýta sa, ako je možné, že l'udské bytosti nadobúdajú svoje presvedčenia o svete na základe stimulácie svojich zmyslov, ktoré sú jediným zdrojom týchto presvedčení. Epistemológia sa v tomto ponímaní stáva kapitolou psychológie, a teda prírodnej vedy. „Študuje prírodný jav, totiž fyzický l'udský subjekt. Tomuto l'udskému subjektu prislúcha istý experimentálne kontrolovaný vstup - napríklad vzorce ožiarenia s najrôznejšími frekvenciami; postupom času tento subjekt vytvorí ako výstup popis trojrozmerného sveta a jeho dejín“ (Quine 2006a, 130 - 131). NE Quine charakterizuje ako skúmanie toho, ako jednotlivec alebo rasa skutočne získavajú spol’ahlivú teóriu vonkajšieho sveta: „Zaoberala by sa otázkou, ako sme my, fyzickí obyvatelia fyzikálneho sveta, dokázali svoju vedeckú teóriu celého tohto sveta vyprojektovat' z našich skromných kontaktov s ním: z obyčajných dopadov lúčov a častíc na povrchy našich tiel“" (Quine 2002, 38).

V rámci TE bola otázka o možnosti poznania ponímaná ako reakcia na skeptickú výzvu a viedla k rozličným pokusom odôvodnit' možnost' poznania a k pokusom o určenie pevných a nespochybnitel'ných základov poznania. „Karteziánsky pokus nájst' istotu bol odvekou motiváciou epistemológie, z pojmového i teoretického hladiska; dospelo sa ale k záveru, že sa týmto hl'adaním len stráca čas" (Quine 2006a, 124), ked’že nevedie $\mathrm{k}$ ničomu inému ako $\mathrm{k}$ skepticizmu. Ak sme si bezprostredne vedomí našich zmyslových dojmov a pocitov, ktoré tvoria jediný základ či východisko poznania sveta, zdá sa, že neexistuje možnost', ako dospiet' k poznaniu vecí vonkajšieho sveta. Quine akcentuje svoj rozchod s karteziánskym snom aj vol'bou fyzikalistického jazyka pre výklad tohto problému - namiesto zmyslov píše o neurálnych receptoroch a ich stimuláciách, a práve takého skúmanie nazýva naturalizovanou epistemológiou (Quine 1994, 27). Ako zdôrazňuje, stimulácia zmyslových receptorov je koniec-koncov jedinou evidenciou, ktorej sa musíme držat', ked' si konštruujeme naše videnie sveta. Preto sa pýta: „Prečo sa teda radšej jednoducho nepozriet', ako taká konštrukcia v skutočnosti prebieha? Prečo sa neuchýlit’ k prostriedkom psychológie?“(Quine 2006a, 125) Epistemológia, ktorá sa stáva kapitolou psychológie študujúcej prírodný jav, teda fyzický l'udský subjekt, stráca svoju normativitu, ako aj apriórny charakter akejsi „prvej filozofie.“

Redefinovanie epistemologickej otázky zacielenej na základy poznania, ako aj metódy epistemologického skúmania, má závažné dôsledky aj pre problém skepticizmu. Podl'a niektorých vyjadrení sa zdá, akoby Quine prijímal rozšírený názor, že práve skepticizmus je ústrednou témou epistemológie: „Pochybnost’ bola často prehlasovaná za matku filozofie. To má punc pravdivosti pre tých z nás, ktorí filozofiu chápeme najmä ako teóriu poznania. Teória poznania totiž pramení z pochybnosti, zo skeptického postoja. Práve pochybnost' nás podnecuje $\mathrm{k}$ tomu, aby sme sa pokúsili rozvinút' teóriu 
poznania“" (Quine 2006b, 138). Ako však dodáva, platí aj opačné pôsobenie - nielen že pochybnost' podnecuje poznanie, ale aj poznanie generuje pochybnost'. V tomto zmysle „skepticizmus je odnožou vedy“ (tamže). Quine, ako sa zdá, neodmieta klasický skepticizmus ako epistemologický problém, ale tvrdí, že descartovské pochybovanie nie je dobrým začiatkom rozvíjania teórie poznania (tamže, 139). Karteziánske pochybovanie vyviera z reflexie medzery medzi zdaním a realitou, medzi snom a skutočnost'ou, čerpá zo zmyslových klamov a ilúzií. Avšak tieto klamy sú klamné iba vzhl'adom na už prijaté či postulované reálne telesá a toto postulovanie fyzických telies je počiatkom elementárnej vedy, ,primitívnej vedy zdravého rozumu“ (tamže, 141). Skeptik v tomto zmysle „parazituje“ na vede a v tomto zmysle skeptické pochybnosti sú vedeckými pochybnost’ami; preto aj riešenie skeptického problému musí podl'a neho vychádzat' z tejto oblasti. Inými slovami, ak sa pýtame na to, ako vieme, že naše poznanie, najlepšie, aké máme, nemôže byt' mylné, pri hl'adaní odpovede sa môžeme opriet' o vedu, napr. v tom, že Darwinova teória prirodzeného výberu ukazuje, že adekvátne poznanie umožňuje prežitie a poznanie je nevyhnutným vedl'ajším produktom prírodného výberu. Samozrejme, darwinizmus poskytuje vel'mi všeobecný náhl'ad a vysvetlenie toho, ako a prečo nadobúdame pravdivé presvedčenia. Detailnejšie vysvetlenie je v kompetencii empirických vied. Úlohu vysvetlit', ako sa poznanie buduje na základe skúsenosti, Quine transponuje do vysvetlenia toho, ako sa formuje naša jazyková kompetencia, ako sa diet’a učí referovat' na predmety, použivat' pozorovacie vety, predikácie - skrátka, ako sa buduje a ako je možná veda ako istá jazyková štruktúra, ktorá je na svojich okrajoch spojená s pozorovaním (Quine 2006b, 145 - 152). ${ }^{10}$

\section{Naturalistický pohl'ad na skepticizmus}

Okrem Quinovho projektu možno do skupiny NE zaradit' všetky prístupy, ktoré spochybňujú tradičnú karteziánsku víziu epistemológie ako hladania istých základov poznania pomocou apriórneho teoretizovania. Namiesto toho vystupujú do popredia výskumy poznania vykonávané pomocou empirického aparátu špeciálnych vied. Hlavným predmetom záujmu naturalistov je skutočný priebeh a charakter l’udského poznávania, opísaný pomocou empirických dát. Tradičný filozofický prístup k poznaniu $\mathrm{s}$ jeho apriórnym charakterom odmietajú ako neužitočný a v horšom prípade scestný pre jeho špekulatívnost' a neprihliadanie na dostupné empirické údaje.

A. Goldman uvádza niekol'ko hlavných charakteristík, v ktorých sa najvýraznejšie rozchádzajú tradičné a naturalistické chápanie epistemológie (Goldman 1986, 1 -2):

1. epistemológia je autonómna a ako náuka o metóde predchádza vedy;

2. epistemológia sa zaoberá konceptuálnou analýzou epistemických pojmov;

${ }^{10}$ Pozri tiež Orenstein $(2001,21)$. 
3. epistemológia rieši myšlienkové paradoxy vedúce $\mathrm{k}$ skepticizmu;

4. epistemológia je štúdium metodológie vo formálnom zmysle;

5. epistemológia má normatívny, a nie deskriptívny charakter.

Naturalisti striktne odmietajú tradičné filozofické chápanie epistemológie, stelesnené $\mathrm{v}$ týchto bodoch, čo má závažné dôsledky aj vzhl'adom na úlohu a význam skepticizmu v rámci tejto disciplíny. Skepticizmus je v očiach naturalistov spätý so špekulatívnym teoretizovaním, ktoré sa usilujú potlačit' a prekonat' v prospech empirických výskumov. Zo svojho hl'adiska tak skepticizmus nepokladajú za skutočný epistemologický problém. Naturalisti sa koncentrujú na opis existujúceho poznania, pričom možnost', že by sme sa plošne mýlili v niektorej celej triede poznatkov, tak ako to naznačuje skepticizmus, vnímajú ako neplauzibilnú až absurdnú.

Odlišnú pozíciu skepticizmu v rámci TE a NE ilustruje H. Kornblith, ktorý približuje kl'účové body karteziánskej tradície v epistemológii, aby ich mohol kontrastovat' s alternatívnym naturalistickým prístupom. Podla neho Descartes v Meditáciách odpovedal na tri základné otázky (Kornblith 1999, 159):

1. Čo je poznanie?

2. Ako je možné poznanie?

3. Čo máme robit', aby sme dosiahli poznanie?

K uvedeným otázkam poznamenáva, že: 1) podl’a Descarta má poznanie fundacionalistický charakter a je zakotvené v základných nespochybnitel'ných poznatkoch; 2) možnost' takého poznania demonštruje v reakcii na skeptické argumenty; 3 ) identifikovat' pravé poznanie je možné tak, že suspendujeme všetky presvedčenia a spätne akceptujeme len tie, ktoré spíňajú kritériá nespochybnitel'nosti (tamže).

Vidíme, že úloha skepticizmu je v karteziánskej tradícii kl'účová. Predstavuje elementárny nástroj na identifikovanie nespochybnitel'ného poznania, ktoré tvorí základy, na ktorých stojí všetko ostatné, odvodené poznanie. Ak na poznanie kladieme požiadavku nespochybnitel'nosti, tak je vhodné ho „otestovat" práve pomocou silnej pochybnosti a sledovat', či takýmto testom prejde. Skepticizmus je z tohto pohl'adu nezastupitel'ný. Epistemológia, v ktorej jadre sa nachádza opísaný postup, logicky predchádza empirické vedy. Na jej začiatku je apriórne určenie racionálnych kritérí poznania, a až potom prichádza na rad zist'ovanie, ktoré presvedčenia im vyhovujú. Epistemický status akýchkol'vek empirických dát tak závisí od toho, či spíňajú predchádzajúce neempirické podmienky.

Descartovým štandardom poznania sa neraz vyčíta, že sú nesplnitel'ne vysoké. Vyžadovanie úplnej imunity voči pochybnosti môže viest' $\mathrm{k}$ drastickému zúženiu bežne predpokladaného rozsahu nášho poznania, a tým de facto $\mathrm{k}$ skepticizmu. Výhrady naturalistov voči TE sú však hlbšie. Naturalisti všeobecne popierajú ostrú dištinkciu medzi 
filozofiou a vedou. Zatial' čo v tradičnom chápaní filozofia predchádza empirickú vedu, tak podl'a naturalistického prístupu poznanie treba skúmat práve pomocou empirických metód. Teda epistemologické problémy naturalisti klasifikujú ako vedecké problémy, ktoré sa dajú a majú riešit' empirickými a inými osvedčenými vedeckými postupmi. Kompetencie na riešenie problémov spätých s poznaním sa takpovediac presúvajú z filozofických kabinetov do laboratórií špeciálnych vied.

S tým úzko súvisí aj otázka normativity epistemológie. Pojem poznania, tak ako je chápaný v TE, je bytostne normatívny. Zahíňa kritériá, ktoré by malo splńňat pravé poznanie, pričom $\mathrm{v}$ karteziánskej tradícii tvoria prostriedok na identifikovanie takýchto kritérií práve skeptické scenáre. Naproti tomu NE sa zaciel'uje skôr na opis reálnych praktík poznávania, a teda charakteristika poznania, ktorú poskytuje, má deskriptívnejší charakter. Rozdiel medzi epistemológiou ako normatívnym podujatím na jednej strane a deskriptívnym podujatím na druhej strane možno označit' za jeden z konštitutívnych kontrastov medzi TE a NE. ${ }^{11}$

Naturalistický prístup k epistemológii, ktorý ju transformuje na empiricky formované štúdiá l'udskej kognície, vytláča tému skepticizmu na perifériu záujmu. Skúmanie poznania naturalisti nechápu ako apriórne vykonávanú pojmovú analýzu, ale ako empirické zist'ovanie čŕt fenoménu poznania ako takého. Zaujíma ich skutočný priebeh a povaha l'udského poznávania, v protiklade $\mathrm{k}$ cibreniu idealizovaného a realite nezodpovedajúceho pojmu poznania, ktoré pripisujú TE. Kornblith tento posun ilustruje prostredníctvom analógie s chémiou: „Tak, ako je opis nášho pojmu hliníka málo zaujímavý pre chémiu, tak aj opis nášho súčasného pojmu poznania, ako verím, by mal byt' málo zaujímavý pre epistemológiu“ (Kornblith 1999, 166). Je zrejmé, že skepticizmus v rámci takto ponímanej NE stráca svoju úlohu, ktorú hral v TE. Skeptické scenáre naznačujúce možnost' principiálneho omylu v našich presvedčeniach sa $\mathrm{z}$ hladiska empirického skúmania reálnych procesov poznávania, ktoré kladie do popredia naturalizmus, javia ako fantastické a neúčelné. Venovat' pozornost' skepticizmu označuje Kornblith priam za „slepú uličku“ epistemologického bádania (tamže). Z hl’adiska NE nemá skepticizmus žiadny význam pre skúmanie poznania, preto je spravidla odmietaný.

Antiskeptický postoj naturalistov tak nie je dôsledkom vyvrátenia skeptických argumentov. Skepticizmus odmietajú vopred ako samoúčelnú intelektuálnu hru, ktorá k skúmaniu reálneho poznania nemá čo povedat', respektíve zvádza ho na irelevantné

\footnotetext{
${ }^{11}$ Vzt'ah medzi deskriptívnym a normatívnym aspektom je v rámci NE o čosi zložitejší. Hoci zástancovia NE presadzujú v prvom rade deskriptívny prístup k skúmaniu poznania, na jeho normativitu celkom nerezignujú. Dokonca aj Quine, ktorý je známy radikálnou verziou NE, pripúšt’a normatívny rozmer svojej koncepcie (pozri Quine 1986). Celkovo však táto otázka tvorí viacvrstvovú a polemickú problematiku, na ktorej komplexné riešenie nemáme v tejto stati priestor. Uspokojíme sa preto s konštatovaním, že pre TE je typický dôraz na normatívny aspekt a pre NE je typický dôraz na deskriptívny aspekt.
} 
špekulatívne cestičky. Vytlačenie skepticizmu z jadra epistemológie umožňuje naturalistom formulovat' pozitívne predpoklady o našom poznaní. Jeden z takých predpokladov hovorí, že kognitívne procesy, ktoré reálne používame, zhruba zodpovedajú procesom, ktoré by sme mali používat' na adekvátne poznávanie. Kornblith tento predpoklad označuje ako „ihriskový psychologizmus“ (angl. ballpark psychologism), ked’že jedny aj druhé kognitívne procesy umiestňuje zhruba na to isté ,ihrisko“ a tvrdí, že ak odmietneme skepticizmus, tak práve takýto predpoklad predstavuje najrozumnejšie východisko skúmania (Kornblith 1994b, 10 - 11). Z hl'adiska TE by uvedený predpoklad mal status nezdôvodnenej domnienky: To, či skutočná tvorba našich presvedčení zodpovedá štandardom adekvátneho poznávania, je otvorená otázka, do ktorej podstatným spôsobom intervenujú aj skeptické možnosti. No z hl'adiska NE, ked' je skepticizmu odopretá jeho relevancia, sa Kornblithom sformulovaný predpoklad javí ako vcelku racionálny.

\section{Kritika naturalistickej reakcie na skepticizmus}

Jedným zo spôsobov, ako sa postavit' voči naturalistickej eliminácii skepticizmu, je diferencovat' medzi filozofickým skepticizmom a bežným, prípadne vedeckým skepticizmom. Pripomeňme, že Quine explicitne charakterizuje skepticizmus ako uvažovanie o rozličných zmyslových ilúziách, ktoré sú však ilúziami len vo vzt’ahu $\mathrm{k}$ skutočným materiálnym predmetom. Odlišovanie kognitívnych prípadov vnímania pravých predmetov od prípadov iluzórneho vnímania kladie do kompetencie vedy a zastáva názor, že ,skeptické pochybnosti sú vedeckými pochybnost’ami“ (Quine 2006b, 139)..$^{12}$ Filozofický skepticizmus sa však spája s úsilím pochopit' l'udské poznanie vo všeobecnosti, so snahou zodpovedat' otázku, ako je poznanie vôbec možné. Túto stratégiu sleduje B. Stroud (Stroud 1979), podla ktorého skeptický nádych problému ako takého je daný tým, že poznanie vonkajšieho sveta je sprostredkované zmyslami, a teda svet môže byt' iný, ako sa nám v zmyslovej percepcii javí. ${ }^{13}$ Pre filozofa, ktorý akceptuje toto východisko, bude pre potvrdenie poznania potrebné vylúčit' možnost' omylu. Poznanie sa stáva filozofickým problémom práve vtedy, ked' si uvedomíme, že svet môže byt' iný, ako sa nám javí, respektíve že naše vnímanie by mohlo byt také isté, aké je, aj keby bol svet odlišný od toho, ako sa nám javí. Riešenie filozofického problému poznania by

\footnotetext{
${ }^{12}$ BonJour ku Quinovej pozícii poznamenáva, že aj ked’ je pravda, že rôzne skeptické úvahy sú často motivované zmyslovými ilúziami, odkazovanie na ilúzie nie je pre skepticizmus rozhodujúce. Fundamentálnou črtou skepticizmu je spochybňovanie adekvátnosti dôvodov pre naše presvedčenia, čo sa dá robit' aj bez špecifického odvolávania na ilúzie - známym príkladom je Humovo spochybnenie indukcie (BonJour 1994, 288).

${ }^{13}$ Treba upozornit', že takéto rozlíšenie medzi tým, ako sa svet javí v zmyslovej percepcii, a tým, aký je v skutočnosti, je pevne previazané s tradičným chápaním zmyslovo daného ako subjektívneho obsahu l'udskej mysle a s predpokladom nejakého „externého“ pohl'adu, z ktorej je toto rozlíšenie vôbec uchopitel'né.
} 
potom malo tkviet' v preukázaní toho, ako je možné skeptickej výzve čelit', alebo si priznat', že skepticizmus je záverom našich skúmaní. ${ }^{14}$

Ak je problém poznania formulovaný takto, nie je t'ažké nahliadnut', že NE naň nemôže dat' odpoved', ked'že, ako už bolo spomenuté, navrhuje zamerat' pozornost' na reálne procesy poznania. Skepticizmus, ktorý je „odnožou vedy“, nie je tým skepticizmom, o ktorom uvažujú filozofi - skúmanie toho, ako nadobúdame poznanie sveta, dokonca ani reflexia toho, ako vieme, že naše „teórie sveta“ sú adekvátne alebo pravdivé, nemôže dat' odpoved' na otázku, ktorú formuluje skeptik, ked’že žiadne možnosti všeobecného a systematického omylu ani nezvažuje. Iste, dalo by sa povedat', že rozumnejšie je prijat hypotézu telies ako hypotézu zlého démona, no nestačí tvrdit', že prvá hypotéza je pravdepodobnejšia alebo rozumnejšia, treba to aj dokázat' či preukázat', čo však NE nerobí (Stroud 1979, 288 - 289). Navyše keby sme brali naturalizovanú stratégiu ako relevantnú pre filozofický problém poznania, dostali by sme sa len $\mathrm{k}$ skeptickému záveru (tamže, 290). ${ }^{15}$ Vyššie uvedené neznamená, že otázky, aké kladie napríklad psychológ o tom, ako ludia nadobúdajú svoje presvedčenia o svete a hladá na ne odpoved' empirickým skúmaním, sú nedôležité - znamená to však, že výsledky takéhoto skúmania nemôžu byt' odpoved'ou na filozofický problém poznania (Stroud 1981, 459). Prívrženci NE by mohli tvrdit', že sám filozofický problém poznania, tak ako bol ponímaný v TE, je zle formulovaný, nekoherentný alebo jalový, avšak takéto tvrdenie by malo byt' opreté o preukázanie, $\mathrm{v}$ čom je tradičná formulácia filozofického problému poznania chybná. ${ }^{16}$ No aj keby sme súhlasili s tým, že skeptické pochybnosti sú vedecké pochybnosti, ako to tvrdí Quine, nemuselo by to znamenat' odmietnutie filozofického skepticizmu ako niečoho prekonaného. Skeptické hypotézy nemožno zhodit' zo stola vyzdvihnutím nejakej empirickej hypotézy: keby sme tak postupovali, bolo by to usudzovanie v kruhu, ked’že skeptické hypotézy nie sú empirickými hypotézami.

Prehliadanie rozdielov medzi filozofickým a bežným, respektíve vedeckým skepticizmom, ktorého sa podl'a Strouda dopúšt’a NE, má vážne epistemologické dôsledky. Jeden z takých dôsledkov súvisí s normatívnym charakterom filozofického problému poznania, ktorý je stelesnený v pojmoch, ako sú evidencia a zdôvodnenie. Quine uvádza pojem evidencie pri charakterizovaní svojho projektu NE: „Vzt’ah medzi skromným vstupom a rozkošateným výstupom je vzt’ahom, ktorý chceme skúmat' $z$ dôvodov vel'mi podobných tým, ktoré epistemológiu motivovali odjakživa - chceme totiž vediet', ako sa evidencia vzt’ahuje k teórii a akým spôsobom naša teória prírody zároveň akúkol’vek

${ }^{14}$ V zmysle Humovho konzekventného skepticizmu, ktorý „nasleduje po vede a skúmaní“ (Hume $1967,189-190)$.

${ }^{15}$ Zdá sa, že niektorí prívrženci NE sú ochotní takýto záver prijat', prinajmenšom Quine, podl’a ktorého v otázke zdôvodnenia poznania prírody sme sa d'alej nedostali: „Humova t’ažkost' je všeobecná l'udská t'ažkost"“(Quine 2006a, 122).

${ }^{16}$ Stroud si všíma Quinov projekt NE, ktorý, ako dôvodí, nič také neposkytuje (Stroud 1981, 461). 
dostupnú evidenciu prekračuje“ (Quine 2006a, 131; kurzíva autori). Lenže ako upozorňuje BonJour, Quine chápe evidenciu inak, ako je bežné vo filozofickej epistemológii. Štandardne sa chápe ako normatívna vlastnost', ktorá určuje racionálnu akceptovatel'nost' svojho predmetu a epistemologicky úzko súvisí so zdôvodnením presvedčení. Quinov projekt empirickej psychológie si však dáva za ciel' čisto deskriptívne vysvetl'ovat' kauzálne vzt’ahy medzi senzorickou stimuláciou (evidenciou) a tvorbou našich presvedčení (teóriami). Ako zdôrazňuje BonJour, takýto projekt nemôže ponúknut' prostriedky pre posúdenie racionálnej akceptovatel’nosti spomenutých vzt’ahov (BonJour 1994, 287), ked’že čisto kauzálny opis nedokáže poskytnút žiadne dôvody v prospech presvedčení, ale ani proti nim. Quine teda používa pojem evidencie bez normatívnych implikácií. Tento problém je lepšie viditel'ný pri presvedčeniach, pri ktorých je namieste istá dávka skepticizmu, ako sú napríklad náboženské alebo okultné presvedčenia. Quinova NE môže uviest' empirický opis príčin, ktoré stoja za vznikom takýchto presvedčení, ale nie je schopný nič povedat' $\mathrm{k}$ ich zdôvodneniu či celkovej epistemickej akceptovatelnosti. Z hladiska kauzálneho výkladu NE teda nerobí rozdiel medzi vedeckými a okultnými presvedčeniami a neponúka žiadny dôvod pre preferovanie jedných pred druhými, čo je epistemologicky neuspokojivé (BonJour 1994, 289).

Quinov projekt NE tak v BonJourových očiach paradoxne vedie ku skepticizmu. Z hladiska NE máme súbor rozličných presvedčení o vonkajšom svete, ale nemáme žiadny racionálny dôvod mysliet' si, že tieto presvedčenia sú pravdivé. A ak sú takéto dôvody nevyhnutnou podmienkou poznania, ako stále predpokladá väššina odborníkov, tak nemáme ani žiadne poznanie. Výsledkom Quinovho poňatia NE je tak ,d'alekosiahla verzia skepticizmu“ (BonJour 1994, 287). Bizarné pritom je, že čast’ našich presvedčení tvoria naturalistické opisy toho, ako senzorická stimulácia vedie k vzniku našich presvedčení. Pokial' ani týmto presvedčeniam NE neposkytuje racionálne dôvody, tak do oblasti skepticizmu vytláča aj svoje vlastné filozofické tvrdenia.

\section{Záver}

Ako sme v článku viackrát zdôraznili, problém skepticizmu je jedným z centrálnych, ak nie hlavným problémom TE, a má svoje dôstojné miesto aj v súčasnej analyticky orientovanej epistemológii. Tiež sme upozornili, že z pohl'adu prívržencov NE skepticizmus sa vysúva na perifériu záujmu, ba úplne stráca svoju relevantnost'. Naturalizovaný prístup k problému poznania, aspoň podl'a jeho priaznivcov, problém skepticizmu „rieši“ tak, že ho rozpúšt’a, eliminuje. Jednou z možných reakcií na takéto tvrdenie by bola otázka, či naturalisti skutočne eliminujú filozofický problém poznania, alebo či nejde skôr o to, že opúšt’ajú slovník, v akom sa skeptický problém formuluje. Bolo by iste lákavé odpovedat' na túto otázku kladne a tvrdit', že ak sa zdá, že existuje nejaký spor medzi TE a NE v otázke skepticizmu, tak toto zdanie je klamlivé, že tu nejde o žiadny 
reálny spor. Ved’ prívrženci jednotlivých „táborov“ hovoria v súvislosti so skepticizmom o odlišných problémoch - kým pre TE je problémom vylúčenie možnosti, že nás klamú zmysly či zlý duch alebo že sme mozgy v kadi, pre NE je problémom opísat' a vysvetlit', ako sa vyvíjajú kognitívne schopnosti a ako na základe podráždenia zmyslových receptorov tvoríme naše poznanie sveta. Vskutku, predmetom sporu medzi TE a NE v súvislosti so skepticizmom nie je sám skepticizmus - nejaká konkrétna skeptická hypotéza, konkrétny skeptický argument, ani súbor skeptických argumentačných stratégií - týmto veciam naturalisti nevenujú takmer žiadnu pozornost', neformulujú voči nim vážne námietky. To, voči čomu namietajú, je charakter epistemologických skúmaní, ktorý je typický pre TE aj súčasnú nenaturalizovanú epistemológiu; to znamená voči apriorizmu, takzvanému filozofovaniu z kresla, konceptuálnej analýze, teda voči prístupu, ktorý uchopuje poznanie (presnejšie pojem poznania) bez akejkol'vek súvislosti s „l’udským poznávaním“, kognitívnou praxou.

Ukazuje sa tak, že spor je metaepistemologický, týka sa charakteru či samej možnosti a legitímnosti epistemológie ako filozofického skúmania, pričom zvažovanie rôznych možností, ako ho rozhodnút či rozriešit', bude závisiet', ako sa nazdávame, od toho, aký postoj zaujmeme k problému normativity. Ak si myslíme, spolu s BonJourom, že epistemológia bez normatívneho aspektu je nepoužitel'ná na ciele, ktoré od epistemológie očakávame, problém skepticizmu zrejme z epistemológie nevylúčime. Námietka voči redukovaniu epistemológie len na čisto deskriptívne podujatie sa javí ako oprávnená, ked’že takéto podujatie nám nepomôže na ceste $\mathrm{k}$ vylepšovaniu korpusu našich presvedčení. Čo však ale nemusí nutne znamenat' odmietanie empirického skúmania našej kognitívnej praxe. Konceptuálnemu podujatiu, vyjasňovaniu našich epistemických pojmov (pojmu poznania, pravdy, evidencie, zdôvodnenia) podl'a nás môžu byt' nápomocné zistenia empirických skúmaní. Medzi tým, ako svet poznávame, a tým, aké by poznanie malo byt', nemusí byt' nepreklenutel'ná priepast' - normativita a deskriptivita sa nemusia navzájom vylučovat'. V takom prípade by sme TE a NE nemuseli chápat' ako alternatívne, navzájom sa vylučujúce prístupy, ale mohli by sme hl'adat' medzi nimi isté prepojenie. Niečo podobné navrhuje aj A. Goldman, ktorý nechce redukovat' celú epistemológiu na NE, ale chce presadit’ istú „del'bu práce“. Filozofická TE môže podla neho robit' evaluáciu výrokov o poznaní: identifikovat' podmienky, za ktorých môžeme presvedčenia chápat' ako poznanie, čiže bude mat' vo svojej kompetencii konceptuálny a normatívny rozmer skúmania poznania. Naproti tomu NE môže skúmat' priebeh a spol'ahlivost' l'udských kognitívnych mechanizmov, čiže bude riešit' procesnú stránku poznávania. Epistemológia sa tak môže zmenit’ na multidisciplinárne podujatie, ktoré Goldman označuje výrazom epistemika (angl. epistemics) (Goldman 1986, 9). Či 
takýto návrh môže byt' úspešný, je vecou d’alšieho (nielen konceptuálneho a apriórneho) skúmania. ${ }^{17}$

\section{Literatúra}

BONJOUR, L. (1994): Against Naturalized Epistemology. Midwest Studies in Philosophy, 19 (1), 283 - 300. DOI: http://dx.doi.org/10.1111/j.1475-4975.1994.tb00290.x

DE CARO, M., MACARTHUR, D. (2004): Introduction: The Nature of Naturalism. In: Mario De Caro - David Macarthur (eds.): Naturalism in Question. Cambridge: Harvard University Press, $1-18$.

DESCARTES, R. (1997): Meditácie o prvej filozofii. Bratislava: Chronos.

FLANAGAN, O. (2008): Varieties of Naturalism. In: Clayton, P. (ed.): The Oxford Handbook of Religion and Science. Oxford: Oxford University Press, 430 - 453.

GOLDMAN, A. I. (1986): Epistemology and Cognition. Cambridge (MA) - London: Harvard University Press.

GREIF, A. (2015): Je skepticizmus stále zaujímavý? Filozofia, 70 (7), 531 - 545.

HAACK, S. (2010): Belief in Naturalism: An Epistemologist's Philosophy of Mind. Logos \& Episte$m e, 1$ (1), 67 - 83. DOI: https://doi.org/10.5840/logos-episteme20101122

HUME, D. (1967): Úvahy o l'udskom rozume. In: Münz, T. (ed.): Antológia z diel filozofov. Novoveká empirická a osvietenská filozofia. Bratislava: Vydavatel'stvo politickej literatúry, $161-200$.

KEIL, G. (2010): Naturalism. In: Moran, D. (ed.): The Routledge Companion to Twentieth Century Philosophy. London - New York: Routledge, 256 - 307.

KEIL, G. (2017): Naturalizmus a l'udská prirodzenost'. In: Szapuová, M., Nuhlíček, M. et al.: Medzi vedou a morálkou. Perspektívy naturalizmu. Bratislava: Univerzita Komenského v Bratislave.

KORNBLITH, H. (1994a): A Conservative Approach to Social Epistemology. In: Schmitt, F. (ed.): Socializing Epistemology. The Social Dimensions of Knowledge. Lanham (Maryland): Rowman and Littlefield, 93 - 110.

KORNBLITH, H. (1994b): Introduction: What is Naturalistic Epistemology? In: Kornblith, H. (ed.): Naturalizing Epistemology. 2nd ed. Cambridge (MA): MIT Press, 1 - 14.

KORNBLITH, H. (1999): In Defense of a Naturalized Epistemology. In: Greco, J. - Sosa, E. (eds.): The Blackwell Guide to Epistemology. Malden (MA): Blackwell, 158 - 169.

LONGINO, H. (1990): Science as Social Knowledge. Values and Objectivity in Scientific Inquiry. Princeton: Princeton University Press.

NELSON, L. H. (1990): Who Knows. From Quine to a Feminist Empiricism. Philadelphia: Temple University Press.

NUHLÍČEK, M., SZAPUOVÁ, M. (2012): Poznámky ku skepticizmu alebo Čo spochybňuje, a čo nespochybňuje skeptik. Filozofia, 67 (2), 147 - 159.

ORENSTEIN, A. (2001): Quine, Willard Van Orman. Organon F, 8 (1), 17 - 39.

ORENSTEIN, A. (2002): W. V. Quine. Chesham: Acumen Publishing Ltd.

PAITLOVÁ, J., JEDLIČKA, P. (2020): Objektivní poznání v kontextu naturalizace filosofie. Philosophia Critica, 6 (1), 37 - 51.

PUTNAM, H. (1981): Brains in a Vat. In: Reason, Truth, and History. Cambridge: Cambridge University Press, $1-22$.

QUINE, W. V. O. (1969): Ontological Relativity. In: Ontological Relativity and Other Essays. New York: Columbia University Press, 69 - 90.

17 Čosi podobné naznačujú aj Paitlová a Jedlička, podl'a ktorých predmetom experimentálne filozofického prístupu môže byt' dokonca aj povaha filozofického bádania ako takého, pričom tento prístup vo filozofii a k filozofii označujú ako „,cenný, legitímny a v zásade komplementárny (teda nie vylučujúci) voči existujúcim špekulatívnym prístupom“ (Paitlová, Jedlička 2020, 49). 
QUINE, W. V. O. (1986): Reply to White. In: Hahn, L. - Schilpp, P. (eds.): The Philosophy of W.V. Quine. La Salle, Ill.: Open Court, 663 - 665.

QUINE, W. V. O. (1994): Hledání pravdy. Praha: Herrmann a synové.

QUINE, W. V. O. (2002): Od stimulu $k$ véde. Praha: Filosofia.

QUINE, W. V. O. (2006a): Naturalizace epistemologie. In: Marvan, T. - Dostálová, L. (eds.): Willard van Orman Quine. Vybrané články k ontologii a epistemologii. Plzeň: Západočeská univerzita v Plzni, 120 - 137.

QUINE, W. V. O. (2006b): Povaha poznání přírody. In: Marvan, T. - Dostálová, L. (eds.): Willard van Orman Quine. Vybrané články k ontologii a epistemologii. Plzeň: Západočeská univerzita v Plzni, $138-152$.

RYDER, J. (2002): Zmierenie pragmatizmu a naturalizmu. Filozofia, 57 (2), 123 - 136.

SELLARS, W. (1963): Science, Perception, and Reality. London: Routledge.

STRAWSON, P. F. (1985): Skepticism and Naturalism: Some Varieties. London: Methuen \& Co. Ltd.

STROUD, B. (1979): The Significance of Scepticism. In: Bieri, P. - Horstmann, R. P. - Krüger, L. (eds.): Transcendental Arguments and Science. Dordrecht: Reidel, 277 - 297.

STROUD, B. (1981): The Significance of Naturalized Epistemology. Midwest Studies in Philosophy, $6(1), 455-471$.

STROUD, B. (1984): The Significance of Philosophical Scepticism. Oxford: Oxford University Press.

STROUD, B. (1996): The Charm of Naturalism. Proceedings and Addresses of the American Philosophical Association, 70 (2), 43 - 55. [online] Dostupné na: https://www.jstor.org/ stable/3131038 (Navštívené: 25. 6. 2020. DOI: 10.2307/3131038

Táto práca bola podporená Agentúrou na podporu výskumu a vývoja na základe Zmluvy č. APVV-18-0178.

Mariana Szapuová

Univerzita Komenského v Bratislave

Filozofická fakulta

Katedra filozofie a dejín filozofie

Gondova 2

81102 Bratislava

Slovenská republika

e-mail: mariana.szapuova@uniba.sk

ORCID ID: https://orcid.org/0000-0003-0146-8871
Martin Nuhlíček

Univerzita Komenského v Bratislave

Filozofická fakulta

Katedra filozofie a dejín filozofie

Gondova 2

81102 Bratislava

Slovenská republika

e-mail: martin.nuhlicek@uniba.sk

ORCID ID: https://orcid.org/0000-0003-0146-8871 